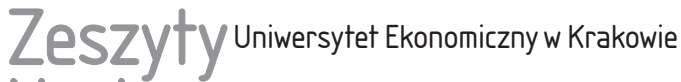 Naukowe
}

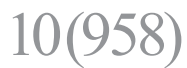

ISSN 1898-6447

Zesz. Nauk. UEK, 2016; 10 (958): 33-49

DOI: 10.15678/ZNUEK.2016.0958.1003

\section{Przesłanki kształtowania wysokości minimalnego wieku emerytalnego*}

\section{Streszczenie}

W artykule poruszono temat zasad kształtowania wysokości minimalnego wieku emerytalnego jako jednego z podstawowych parametrów systemów emerytalnych. Za główny cel przyjęto uzupełnienie debaty na temat ustawowego wieku emerytalnego o rozważania o charakterze metodycznym, perspektywę historyczną, a także o krytyczną analizę argumentów wysuwanych w kontekście podnoszenia oraz zrównywania wieku emerytalnego kobiet i mężczyzn. Na podstawie przeglądu piśmiennictwa, rozważań teoretycznych oraz najnowszych danych empirycznych przeanalizowano rolę wieku emerytalnego we współczesnych systemach emerytalnych, a także argumenty wysuwane na rzecz podwyższania oraz zrównywania wieku emerytalnego kobiet i mężczyzn. W rezultacie przeprowadzonych analiz uzasadniono tezę badawczą, zgodnie z którą zachodzące przemiany społeczno-gospodarcze skutkują koniecznością modyfikacji dotychczasowego podejścia do ustalania wieku zakończenia aktywności zawodowej, jednakże zmiany w tym zakresie nie mogą być arbitralne, oderwane od polityki społecznej i nastawione na realizację wyłącznie doraźnych celów politycznych.

Słowa kluczowe: wiek emerytalny, emerytura, system emerytalny, wyrównywanie wieku emerytalnego, podnoszenie wieku emerytalnego.

Klasyfikacja JEL: J26; H55, J18.

Tomasz Jedynak, Uniwersytet Ekonomiczny w Krakowie, Katedra Zarządzania Ryzykiem i Ubezpieczeń, 31-510 Kraków, ul. Rakowicka 27, e-mail: tomasz.jedynak@uek.krakow.pl

* Publikacja stanowi wynik realizacji tematu badawczego dofinansowanego ze środków MNiSW przyznanych Wydziałowi Finansów Uniwersytetu Ekonomicznego w Krakowie na badania dla młodych naukowców oraz uczestników studiów doktoranckich. 


\section{Wprowadzenie}

Spośród wszystkich parametrów charakteryzujących współczesne systemy emerytalne jednym z najbardziej kontrowersyjnych, a przez to wzbudzającym najwięcej emocji, jest wiek emerytalny. Biorąc pod uwagę, że podjęcie decyzji o zakończeniu aktywności zawodowej i przejściu na emeryturę jest jednym z kluczowych momentów w życiu każdego człowieka, sytuacja ta nie powinna jednak zaskakiwać. W Polsce po zmianach wprowadzonych w 2012 r. na mocy tzw. ustawy podwyższającej wiek emerytalny [Ustawa z dnia 11 maja 2012...] publiczna debata o minimalnym ustawowym wieku emerytalnym wydawała się przynajmniej na jakiś czas - zakończona. Silny sprzeciw społeczeństwa względem podniesienia i zrównania minimalnego wieku emerytalnego dla kobiet i mężczyzn, a także ostatnie zmiany na scenie politycznej sprawiły jednak, że dyskusja ta rozgorzała na nowo. Skrajny antagonizm na linii rząd-opozycja powoduje, że w trwającej dyskusji podnoszone są niemal wyłącznie argumenty o charakterze politycznym i populistycznym, nieuwzględniające przesłanek merytorycznych. Stąd też głównym celem artykułu jest uzupełnienie tej debaty o rozważania o charakterze metodycznym, perspektywę historyczną, a także o krytyczną analizę argumentów wysuwanych w kontekście podnoszenia oraz zrównywania wieku emerytalnego kobiet i mężczyzn. W opracowaniu autor stawia tezę, że zachodzące przemiany społeczno-gospodarcze skutkują koniecznością modyfikacji dotychczasowego podejścia do ustalania wieku zakończenia aktywności zawodowej, ale zmiany w tym zakresie nie mogą być arbitralne, niespójne z polityką społeczną i nastawione na realizację wyłącznie doraźnych celów politycznych.

\section{Wiek emerytalny a system emerytalny}

System emerytalny to istniejące rozwiązania instytucjonalne zmierzające do zapewnienia uczestnikom tego systemu niezarobkowych środków na utrzymanie na okres starości [Szumlicz 2005, s. 243]. Podstawowym celem systemu emerytalnego jest zapewnienie uczestnikom dochodów w okresie po zakończeniu przez nich aktywności zawodowej [Góra 2003, s. 37]. W szerszym ujęciu cele funkcjonowania systemów emerytalnych obejmują również: pomoc dla najuboższych członków społeczeństwa, redystrybucję dochodów, a także realizację innych celów ekonomicznych i społecznych, takich jak wzrost gospodarczy lub polityka prorodzinna [Barr i Diamond 2014, s. 37].

Jednym z kluczowych parametrów każdego systemu emerytalnego jest ustalenie momentu, kiedy jego uczestnicy nabywają prawo do skorzystania z uprawnień emerytalnych. Moment ten z reguły jest określany za pomocą tzw. minimalnego 
wieku emerytalnego (alternatywnie może to być również staż pracy lub staż ubezpieczeniowy). Minimalny wiek emerytalny jest definiowany jako ustalona granica wieku człowieka, której osiągnięcie daje prawo odejścia z rynku pracy i uzyskiwania świadczeń emerytalnych. Ze względów praktycznych minimalny wiek emerytalny jest $\mathrm{z}$ reguły określany za pomocą wieku metrykalnego i jest ustalany na jednakowym poziomie dla wszystkich uczestników systemu.

J. Piotrowski [1966, s. 121-128] jeszcze na długo przed rozpoczęciem obecnej dyskusji o wieku emerytalnym pisał, że przy określaniu wieku, kiedy ubezpieczony może przerwać pracę, powinno się uwzględniać cztery następujące przesłanki: zabezpieczenie (biologiczne uwarunkowania procesu starzenia się), wysługę (zachowanie proporcji pomiędzy okresem ubezpieczenia a okresem pobierania świadczenia), zatrudnienie (uwzględnienie sytuacji na rynku pracy) i koszty (uwzględnienie sytuacji finansowej funduszu ubezpieczenia społecznego) (cyt. za: [Zieleniecki 2015, s. 511]). Z kolei W. Szubert [1987, s. 104-106] utrzymywał, że przy ustalaniu wieku emerytalnego poza eksponowanymi dziś zmianami demograficznymi i społecznymi powinno się uwzględniać również czynniki, takie jak: długofalowe tendencje w zakresie kształtowania się stanu zdrowia ludności, płeć, rodzaj wykonywanej pracy (obniżenie wieku emerytalnego może dotyczyć np. osób wykonujących prace szczególnie uciążliwe, niebezpieczne i szkodliwe dla zdrowia), sytuację na rynku pracy (wiek emerytalny bezpośrednio wpływa na zasób siły roboczej).

We współczesnych analizach ekonomicznych system emerytalny jest rozpatrywany: 1) z perspektywy jednostki - jako narzędzie alokacji dochodu w cyklu życia, 2) z perspektywy makroekonomicznej - jako narzędzie podziału PKB pomiędzy pokolenie pracujących i niepracujących [Góra 2003, s. 19].

W przypadku przyjęcia jednostkowej perspektywy postrzegania systemu emerytalnego użytecznym narzędziem do analizy roli wieku emerytalnego jest model faz ryzyka starości zaproponowany przez T. Szumlicza [2005, s. 242-243]. W modelu tym wyróżnia się dwie fazy uczestnictwa jednostki w systemie emerytalnym: fazę akumulacji oszczędności oraz fazę ich konsumpcji (por. rys. 1). Przy założeniu stałego przeciętnego momentu rozpoczęcia aktywności zawodowej oraz niezmiennej przeciętnej długości trwania życia im wyższy jest wiek emerytalny, tym dłuższy jest okres akumulacji, a krótszy okres korzystania z uprawnień emerytalnych i na odwrót. Warto w tym miejscu nadmienić, że zachodzące przemiany w strukturze społeczeństwa oraz przeobrażenia na rynku pracy powodują, że klasyczny model uzupełnia się obecnie o nowe elementy. W szczególności wyróżnia się okresy wczesnej starości, późnej starości oraz niedołężnej starości, które różnią się od siebie pod względem poziomu zdrowia oraz aktywności społecznej i ekonomicznej jednostek, co nie pozostaje bez wpływu na zasady ustalania wieku emerytalnego [Rutecka 2015, s. 186]. 


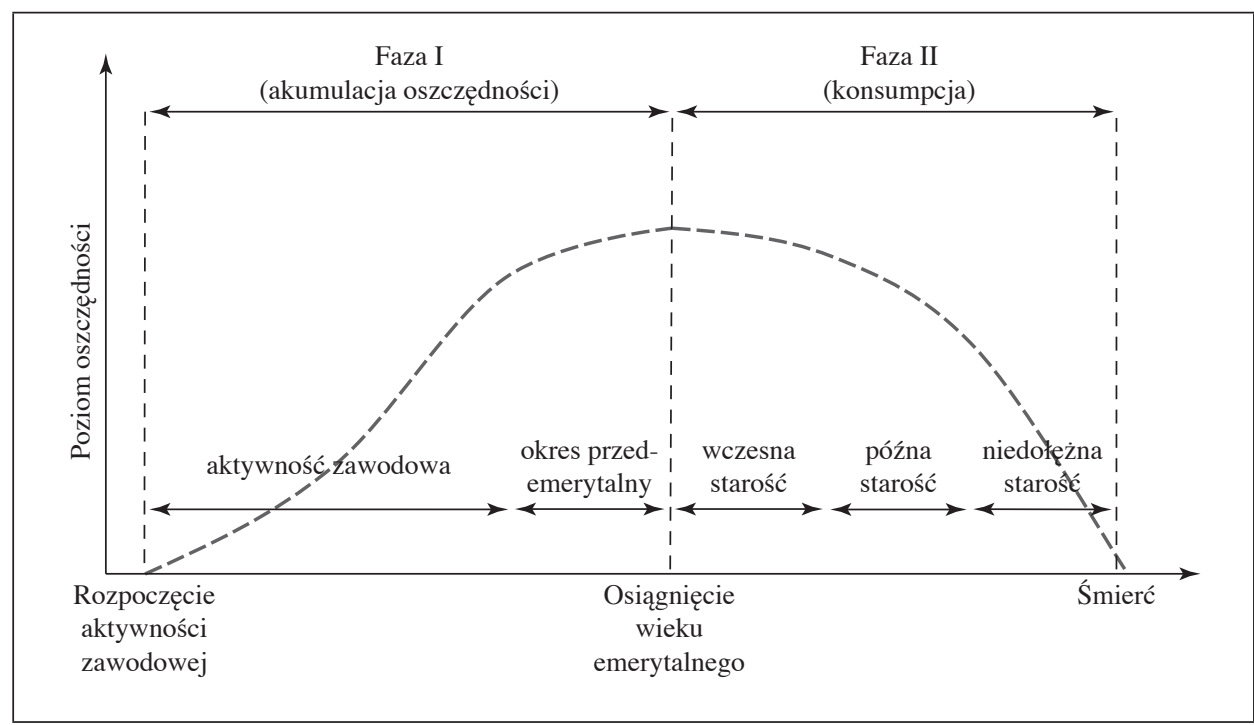

Rys. 1. Model uczestnictwa jednostki w systemie emerytalnym

Źródło: opracowanie własne.

Z perspektywy makroekonomicznej wiek emerytalny jest wielkością, która dzieli populację na dwie kategorie ${ }^{1}$ : osoby w wieku produkcyjnym oraz osoby w wieku poprodukcyjnym (emerytów). Odnosząc ten podział do podstawowej wielkości makroekonomicznej, jaką jest PKB, system emerytalny traktuje się jako sposób dokonywania podziału bieżącego PKB pomiędzy pokolenie pracujących $\left(\mathrm{PKB}^{W}\right)$ i pokolenie emerytów $\left(\mathrm{PKB}^{R}\right)$, przy czym $\mathrm{PKB}^{W}$ odzwierciedla część PKB służącą opłaceniu czynników produkcji, a PKBR określa rozmiary systemu emerytalnego i ukazuje część całkowitego PKB przeznaczaną na spłatę zobowiązań, które pokolenie emerytów nabyło w trakcie aktywności zawodowej [Góra 2003, s. 46]. Zależność tę można zapisać równaniem:

$$
\mathrm{PKB}=\mathrm{PKB}^{W}+\mathrm{PKB}^{R} \text {. }
$$

W prezentowanym ujęciu wzajemne proporcje $\mathrm{PKB}^{W}$ i $\mathrm{PKB}^{R}$ zależą przede wszystkim od konstrukcji systemu emerytalnego, w tym wysokości wieku emerytalnego oraz struktury demograficznej społeczeństwa. Oznacza to, że przy założeniu stałości struktury demograficznej oraz innych elementów budowy systemu emerytalnego im wyższy jest wiek emerytalny, tym mniejsza część PKB przeznaczana jest na finansowanie potrzeb pokolenia emerytów, a większa na wynagradzanie czynników produkcji będących w posiadaniu pokolenia pracującego.

${ }^{1}$ Dla jasności wywodu pominięto dzieci i młodzież uczącą się, które nie należą do żadnej z tych kategorii. 
W efekcie zwiększa się więc zaangażowanie tych czynników w proces produkcji, co prowadzi do zwiększenia tempa wzrostu PKB [Góra 2003, s. 63].

Przyjmując za punkt wyjścia analizy systemu emerytalnego kwestie społeczne, wyróżnić można dwa podejścia do zagadnienia emerytury [Jończyk 2001, s. 146; Góra 2003, s. 48]:

1) system emerytalny jest sposobem finansowania niedołężnej starości, a emerytura jest świadczeniem mającym zapewnić ochronę przed ryzykiem utraty dochodów z powodu wieku,

2) system emerytalny jest narzędziem alokacji dochodu w cyklu życia, a emerytura jest świadczeniem nabytym w zamian za zasługi, premią za długoletnią pracę.

Przyjęcie któregoś z tych podejść ma duże znaczenie dla sposobu określania minimalnego wieku emerytalnego. Jeżeli bowiem przyjąć, że system emerytalny jest narzędziem zapobiegania niedołężnej starości, to minimalny wiek emerytalny powinien odpowiadać uśrednionemu dla populacji momentowi, kiedy jednostki nie są już w stanie podejmować aktywności zawodowej. Z kolei przy założeniu, że emerytura jest świadczeniem nabytym w zamian za zasługi, minimalny wiek emerytalny powinien kształtować się na poziomie umożliwiającym adekwatną do potrzeb i preferencji uczestników systemu alokację dochodu w cyklu życia.

Na kwestię ustalania wysokości minimalnego wieku emerytalnego duży wpływ ma również odróżnienie systemów emerytalnych o zdefiniowanym świadczeniu oraz systemów o zdefiniowanej składce. W systemach o zdefiniowanym świadczeniu wysokość emerytury obliczana jest zgodnie z ustaloną i gwarantowaną przez państwo formułą uwzględniającą wcześniejsze zarobki i staż pracy². W przypadku tego typu systemów prawo do emerytury zależy bezpośrednio od przekroczenia bariery minimalnego wieku emerytalnego, ale jej wysokość pozostaje bez ścisłego związku z tym parametrem. W systemach o zdefiniowanej składce wysokość emerytury $E$ zależy od sumy zgromadzonych przez opłacanie składek uprawnień (oszczędności) emerytalnych $S$ oraz przewidywanej dalszej długości trwania życia na emeryturze $p d t z$. Zależność ta wyraża się wzorem:

$$
E=\frac{S}{p d t z}
$$

Wysokość emerytury w systemie emerytalnym o zdefiniowanej składce jest więc podwójnie skorelowana z wiekiem przejścia na emeryturę. Wydłużenie

2 Przykładem jest tutaj „stary” system emerytalny w Polsce, w którym obowiązywał następujący wzór na wysokość emerytury: $E=24 \% K b+(s \cdot 1,3 \% \mathrm{P})+(n s \cdot 0,7 \% P)$, gdzie: $K b-$ kwota bazowa wynosząca $100 \%$ kwoty przeciętnego miesięcznego wynagrodzenia ze wskazanego przez ustawodawcę okresu, pomniejszonego o potrącone od ubezpieczonych składki na ubezpieczenie społeczne, $s$ - okresy składkowe, $n s$ - okresy nieskładkowe, $P$ - podstawa wymiaru, przychody ubezpieczonego z określonego okresu. 
aktywności zawodowej wpływa bowiem zarówno na zwiększenie sumy nabytych uprawnień emerytalnych, jak i skrócenie przeciętnej dalszej długości trwania życia na emeryturze. Analogicznie skrócenie okresu aktywności zawodowej skutkuje zmniejszeniem sumy nabytych uprawnień oraz wydłużeniem przeciętnej długości trwania życia na emeryturze.

Rozpatrując teoretyczne aspekty problematyki wieku emerytalnego, nie można pominąć jeszcze jednej ważnej kwestii, jaką jest rozróżnienie oficjalnego (ustawowego, formalnego) oraz efektywnego (faktycznego, realnego) wieku emerytalnego. Oficjalny wiek emerytalny to formalna granica wieku uprawniająca do pobierania świadczeń emerytalnych. Efektywny wiek emerytalny to wiek, w którym uczestnik systemu emerytalnego rzeczywiście kończy aktywność zarobkową opuszcza rynek pracy. W praktyce efektywny wiek emerytalny może być wyższy lub niższy od oficjalnego. Pierwsza sytuacja ma miejsce jedynie wówczas, gdy większość uczestników systemu emerytalnego pomimo przekroczenia ustawowego minimalnego wieku emerytalnego i nabyciu prawa do emerytury kontynuuje aktywność ekonomiczną. W praktyce dużo powszechniejsza jest sytuacja druga, w której efektywny wiek emerytalny jest niższy od oficjalnego. Przyczyny tego zjawiska mogą być dwojakie. $Z$ jednej strony do wczesnego opuszczania rynku pracy przyczyniają się wbudowane we współczesne systemy emerytalne mechanizmy umożliwiające wcześniejsze przechodzenie na emeryturę, rozwiązania umożliwiające uzyskanie prawa do emerytury pod warunkiem przepracowania określonej liczby lat lub zgromadzenia zdefiniowanego kapitału emerytalnego, a także obniżony wiek emerytalny dla wybranych grup zawodowych [Benio 2014, s. 70-71]. Z drugiej strony nie ma wystarczających zachęt systemowych do pracy po osiągnięciu oficjalnego wieku emerytalnego, przy czym nie chodzi tu wyłącznie o zachęty o charakterze finansowym, ale również o takie czynniki, jak: warunki pracy, stan rynku pracy, dyskryminacja wiekowa, struktura przemysłowa gospodarki, jakość opieki medycznej [Staniec i Depta 2013, s. 283-284]. Warto odnotować, że różnica pomiędzy oficjalnym a efektywnym wiekiem emerytalnym mężczyzn w Polsce - 3,2 roku, jest największa spośród wszystkich krajów OECD. Z kolei w przypadku kobiet analogiczna miara przyjmuje wartość 0,7 roku, co stanowi średni wynik na tle krajów OECD [OECD 2015, s. 134].

Na zakończenie teoretycznych rozważań o roli wieku emerytalnego we współczesnych systemach emerytalnych należy podkreślić, że niezależnie od metody prowadzenia analizy formalna granica minimalnego wieku emerytalnego ma zawsze charakter umowny. Zarówno jednostkowy układ preferencji dotyczących alokacji dochodu w cyklu życia, jak i proces starzenia się mają charakter indywidualny. Dla całej populacji oba te czynniki są zmiennymi ciągłymi, co powoduje że arbitralne ustalenie minimalnego wieku emerytalnego zawsze oznacza mniejsze lub większe niedostosowanie do potrzeb jednostki. Zasady ustalania 
powszechnego minimalnego wieku emerytalnego powinny w skali populacji minimalizować ten efekt niedopasowania.

\section{Wiek emerytalny w perspektywie historycznej}

Obecnie obserwowana jest tendencja do podnoszenia oraz zrównywania wieku emerytalnego kobiet i mężczyzn [OECD 2015, s. 135]. Analiza zasad kształtowania minimalnego wieku emerytalnego obejmująca ponad wiekową tradycję funkcjonowania systemów emerytalnych prowadzi jednak do wyodrębnienia dwóch okresów, w których występowały różne trendy w tym zakresie [Muszalski 2009]:

1) w pierwszym okresie (od powstania pierwszych systemów emerytalnych do lat 70. XX w.) minimalny wiek uprawniający do otrzymywania świadczeń emerytalnych był systematycznie obniżany ${ }^{3}$. Wśród przyczyn tego zjawiska wymienia się: zmianę podejścia do roli emerytury (z biegiem czasu emerytura zaczęła być postrzegana jako świadczenie nabyte w zamian za długoletnią pracę), wzrost zamożności społeczeństwa, który umożliwiał zmiany w zakresie redystrybucji dochodu w społeczeństwie, a także niekorzystne uwarunkowania rynku pracy (w szczególności bezrobocie wśród kobiet, które na skutek procesów emancypacyjnych w pierwszej połowie XX w. niemal podwoiły dostępny zasób siły roboczej). Nie bez znaczenia były również czynniki polityczne - chęć uzyskania poparcia społeczeństwa;

2) w drugim okresie (od lat 70. XX w.) wcześniejsza tendencja odwróciła się. Od tego czasu podejmowane były inicjatywy zmierzające do podniesienia wieku emerytalnego. Głównym powodem tych zmian były postępujące przemiany w strukturze społeczeństwa, określane mianem drugiego przejścia demograficznego. Krajami, które jako pierwsze podniosły minimalny wiek emerytalny, były [Muszalski 2009, s. 8-9]: USA (1983 r.), Włochy (1992 r.), Austria (1992 r.) Grecja (1993 r.) i Portugalia (1999 r.). W późniejszych latach podobne reformy przeprowadzone zostały m.in. w Niemczech (2007 r.), Nowej Zelandii (2010 r.) oraz Australii (2013 r.).

Tendencje w zakresie kształtowania wieku emerytalnego w Polsce w ciągu minionych stu lat były analogiczne do tych obserwowanych w skali międzynaro-

3 W. Muszalski [2009, s. 7] podaje przykład Niemiec, gdzie początkowo (1889 r.) wiek emerytalny ustalono na poziomie 70 lat. Następnie w 1913 r. (pracownicy umysłowi) i w $1923 \mathrm{r}$. (robotnicy) wiek ten obniżono do 65 lat. W 1929 r. ustalono, że dla bezrobotnych pracowników umysłowych wiek emerytalny będzie wynosił 60 lat. Analogiczne rozwiązanie dla bezrobotnych robotników wprowadzono w $1957 \mathrm{r}$. W tym samym roku obniżono wiek emerytalny dla kobiet (60 lat). W 1972 r. dopuszczono dla osób długo ubezpieczonych możliwość przechodzenia na emeryturę w wieku 63 lat, a dla pobierających renty inwalidzkie w wieku 60 lat. Podobne procesy zachodziły również w Wielkiej Brytanii, Irlandii, Szwecji, Danii oraz Francji. 
dowej [Muszalski 2009]. Początkowo wiek emerytalny dla pracowników umysłowych został ustalony na poziomie 60 lat dla kobiet oraz 65 lat dla mężczyzn (1927 r.), a dla robotników - 65 lat dla kobiet i mężczyzn (1933 r.). Po wojnie (1954 r.) ustawowy wiek emerytalny dla kobiet wynosił 60 lat, a dla mężczyzn - 65 lat. Wprowadzony został wówczas również obniżony o 5 lat wiek emerytalny dla zatrudnionych pod ziemią i w warunkach szkodliwych dla zdrowia. W 1975 r. dopuszczone zostało wcześniejsze przechodzenie kobiet na emeryturę w wieku 55 lat. Następnie w latach 1982-1983 rozszerzono zakres uprawnionych do wcześniejszego przechodzenia na emeryturę, a także uprawnienia wybranych grup zawodowych. W latach 90 . w toku prac na reformą systemu emerytalnego postulowano ustalenie jednolitego dla obu płci wieku emerytalnego na poziomie 62 lat. Ostatecznie jednak wobec braku woli politycznej zaniechano wprowadzenia tego rozwiązania i w zreformowanym systemie utrzymane zostały dotychczasowe zasady. Podobny los spotkał również projekt podniesienia i zrównania wieku emerytalnego na poziomie 65 lat zaproponowany przez J. Hausnera w 2004 r. Pierwsze istotne zmiany w zakresie ustalania wieku emerytalnego nastąpiły dopiero w 2008 r., kiedy to ograniczono zakres możliwości wcześniejszego przechodzenia na emeryturę.

\section{Przesłanki ustalania wieku emerytalnego}

\subsection{Uwagi ogólne}

Zarówno w piśmiennictwie, jak i w debacie publicznej zagadnienia podwyższania oraz zrównywania wieku emerytalnego są z reguły omawiane łącznie. Należy jednak zauważyć, że przesłanki leżące u podstaw zrównywania (różnicowania) oraz podwyższania (obniżania) wieku emerytalnego opierają się niekiedy na różnych racjach. Stąd też pomimo niezaprzeczalnego związku pomiędzy tymi dwoma zagadnieniami w dalszej części tekstu omówiono je oddzielnie, a syntezę spostrzeżeń płynących z przeprowadzonych analiz zawarto w podsumowaniu. Ponadto biorąc pod uwagę, że w najnowszym piśmiennictwie prezentowanych jest wiele zestawień, w których porównywane są: aktualny i docelowy wiek emerytalny w poszczególnych krajach [Niewiadomska 2013, Klimkiewicz 2013, Bednarczyk 2015], sposób rozłożenia w czasie procesu jego podnoszenia [Guzikowski 2012, European Commission 2015] oraz oczekiwana długość życia na emeryturze w różnych państwach [Bera i Walczak 2012] ${ }^{4}$, w opracowaniu zrezygnowano z ich

${ }^{4}$ Powszechnie dostępne dane źródłowe w tym zakresie znaleźć można w [European Commission 2016, OECD 2015]. 
prezentowania. Uwagę skoncentrowano natomiast na analizie różnych argumentów wysuwanych w dyskusji o zrównywaniu oraz podwyższaniu wieku emerytalnego.

\subsection{Zrównywanie wieku emerytalnego}

Z uwagi na dominujące $w$ dzisiejszym świecie przekonanie o równości płci we wszystkich aspektach społeczno-kulturowych i ekonomicznych (egalitaryzm płciowy) analizę problematyki zrównywania wieku emerytalnego należy rozpocząć od wskazania przesłanek, które w przeszłości stanowiły uzasadnienie wprowadzenia rozwiązań różnicujących minimalny wiek emerytalny kobiet i mężczyzn. Próba usystematyzowania tych przesłanek prowadzi do wyróżnienia następujących grup przyczyn różnicowania wieku emerytalnego:

1) przyczyny o charakterze ekonomicznym (niedostatek miejsc pracy w gospodarce oraz strukturalne niedopasowanie rynku pracy do zawodów wykonywanych przez kobiety),

2) przyczyny o charakterze społecznym (rola kobiet jako matek i babć wychowujących dzieci, umożliwienie małżonkom przechodzenia na emeryturę w zbliżonym czasie, wynikające $\mathrm{z}$ tradycji dodatkowe role kobiet $\mathrm{w}$ gospodarstwach domowych),

3) przyczyny o charakterze biologicznym (słabość fizyczna przyspieszająca zużycie organizmu w trakcie wykonywania różnych ról społecznych i zawodowych, szczególne uwarunkowania związane z ciążą),

4) przyczyny o charakterze politycznym (potrzeba uprzywilejowania wyrównawczego w związku z utrzymującą się dyskryminacją kobiet na rynku pracy, uzyskanie doraźnego poparcia politycznego, powoływanie się na wieloletnie tradycje itp.).

Dynamiczne przemiany społeczno-gospodarcze, które zaszły w ciągu minionych kilkudziesięciu lat, powodują, że obecnie część z przytoczonych powyżej przesłanek jest nieaktualna, a znaczenie innych wydatnie zmalało. W szczególności na skutek zjawisk, takich jak wzrost znaczenia sektora usług, rozwój gospodarki opartej na wiedzy czy mechanizacja produkcji, słuszne niegdyśs stwierdzenia o strukturalnym niedostosowaniu popytu na pracę do zawodów wykonywanych przez kobiety są już dzisiaj nieprawdziwe. Biorąc pod uwagę wysokość stóp bezrobocia [GUS 2016b], nie można również nadal utrzymywać, że w całej gospodarce ma miejsce długotrwała nadpodaż pracy jako takiej. Istotnie zmienił się też model współczesnej rodziny (np. zanikanie rodzin wielopokoleniowych, zmniejszanie się liczby dzieci, rozluźnienie więzów małżeńskich i rodzinnych) oraz podział ról społecznych (kobiety są aktywne zawodowo, mężczyźni wykonują obowiązki domowe), co powoduje, że argumenty odwołujące się do tradycyjnego podziału ról na kobiece i męskie coraz częściej stają się bezpodstawne. Należy również 
zauważyć, że w świetle danych demograficznych kobiety nie tracą wcale wcześniej od mężczyzn zdolności do pracy. Przeciwnie, to kobiety statystycznie żyją dłużej, a w póńniejszym okresie życia cechują się przeciętnie lepszym stanem zdrowia od mężczyzn. Przykładowo w 2014 r. w Polsce przeciętna dalsza długość trwania życia w wieku 65 dla mężczyzn wynosiła 15,87 lat, a dla kobiet - 20,18 lat [GUS 2016c]. W tym samym roku oczekiwana długość życia w zdrowiu w wieku 65 lat dla Polaków była równa 7,5 lat, a dla Polek - 8,1 lat [Eurostat 2016].

Analiza przesłanek różnicowania wieku emerytalnego zakwalifikowanych do grupy przyczyn o charakterze politycznym prowadzi do wniosku, że o ile część z nich może mieć rzeczowe uzasadnienie (np. uprzywilejowanie wyrównawcze ${ }^{5}$ ), to pozostałe, mające głównie populistyczny charakter, są słabo umotywowane. Przykładowo powoływanie się na wieloletnie tradycje w zakresie niższego wieku emerytalnego kobiet [Tkaczuk 2014, s. 199] nie może być podstawą do utrzymywania jego zróżnicowania, a wzgląd na ogólnoeuropejskie tendencje [Tkaczuk 2014, s. 199] nie może być wyłącznym powodem jego zrównywania.

Niezależnie od wskazanych uprzednio przesłanek wydaje się, że obecnie kluczowym argumentem w dyskusji o zrównywaniu wieku emerytalnego w Polsce są kwestie finansowe będące pochodną konstrukcji systemu emerytalnego. Wprowadzony w $1999 \mathrm{r}$. „,nowy” system emerytalny opiera się na formule zdefiniowanej składki, co - jak już wspomniano - powoduje, że wiek przejścia na emeryturę wydatnie wpływa na wysokość świadczeń emerytalnych (por. wzór (1)). W tym miejscu zaznaczyć jednak trzeba, że obowiązujące obecnie w Polsce rozwiązania zakładają stosowanie uśrednionych dla obu płci tablic dalszego trwania życia, co eliminuje wpływ różnic w przeciętnej długości życia kobiet i mężczyzn na wysokość ich świadczeń emerytalnych (oraz de facto oznacza redystrybucję dochodu od mężczyzn do kobiet). Niemniej wysokość świadczeń emerytalnych pozostaje silnie uzależniona od sumy zgromadzonych składek, która z kolei bezpośrednio zależy od długości okresu aktywności zawodowej. Pomijając w tym miejscu kwestie ewentualnej możliwości wykonywania pracy zarobkowej po przejściu na emeryturę, stwierdzić należy, że zróżnicowany wiek emerytalny dla kobiet i mężczyzn nieuchronnie skutkuje dysproporcją w wysokości otrzymywanych emerytur. O ile zatem obowiązująca w „starym” systemie emerytalnym formuła zdefiniowanego świadczenia powodowała, że niższy wiek emerytalny (i krótszy wymagany staż ubezpieczeniowy kobiet) był pewnego rodzaju przywilejem, to przy formule zdefiniowanej składki niższy wiek emerytalny można traktować jako przejaw dyskryminacji kobiet [Szczepańska 2011, s. 182].

\footnotetext{
${ }^{5}$ Por. [Wyrok Trybunału... 2010, Szczepańska 2011].
} 


\subsection{Podwyższanie wieku emerytalnego}

Wśród argumentów podnoszonych na rzecz podwyższania wieku emerytalnego dominującą rolę odgrywa ten odnoszący się do wzrostu przeciętnej długości trwania życia. Występowanie tego zjawiska w krajach rozwiniętych jest bezsporne, a pojawiające się wśród badaczy rozbieżności w jego ocenie dotyczą jedynie jego nasilenia i przyszłego przebiegu. Trzeba jednak zwrócić uwagę, że rozpatrując wpływ wydłużania się długości trwania życia na minimalny wiek emerytalny, nie powinno się analizować wartości bezwzględnych, a raczej prognozy dotyczące dalszego trwania życia w zdrowiu. Należy w tym miejscu również wyraźnie podkreślić, że potrzeba podwyższania wieku produkcyjnego nie wynika wyłącznie $\mathrm{z}$ wydłużania się życia ludzkiego, ale z zaburzenia dotychczasowych proporcji pomiędzy liczbą ludności pracującej i niepracującej [Murkowski 2013, s. 274]. Zaburzenie to jest spowodowane ogólnym procesem starzenia się społeczeństwa, na który poza wydłużaniem się długości trwania życia wpływa również spadek dzietności, zmniejszenie odsetka ludności umierającej przedwcześnie, a także wzrost przeciętnej długości pobierania edukacji, co opóźnia wejście na rynek pracy kolejnych roczników. W ujęciu statystycznym zmiany proporcji pomiędzy liczbą ludności pracującej i niepracującej obrazują współczynnik obciążenia demograficznego oraz współczynnik obciążenia ekonomicznego. W przypadku Polski szacuje się, że w okresie 2013-2060 pierwszy z tych współczynników wzrośnie z poziomu $21 \%$ do $61 \%$, a drugi - z $33 \%$ do $87 \%$ [European Commission 2015, s. 358 $]^{6}$.

Zwolennicy podwyższania minimalnego wieku emerytalnego wskazują, że istotną przesłanką przemawiającą na korzyść tego rozwiązania jest pozytywny wpływ odłożenia w czasie momentu zaprzestania aktywności zawodowej na wysokość stopy zastąpienia [Guzikowski 2012, s. 14]. Związek ten wynika wprost z formuły zdefiniowanej składki i jest bezdyskusyjny. Znaczenie tego argumentu dodatkowo potęgują prognozy dotyczące przyszłych stóp zastąpienia w Polsce, zgodnie z którymi będą one kształtować się na niższym niż obecnie poziomie oraz nie będą adekwatne do oczekiwań i potrzeb ubezpieczonych. Przykładowo Komisja Europejska [European Commission 2015] przewiduje stopę zastąpienia w 2060 r. w Polsce na poziomie ok. 29\%, OECD [2015] szacuje, że w 2049 r. wskaźnik ten będzie wynosił ok. 53\%, a prognozy Aviva [Mind the Gap...2016] mówią o stopie zastąpienia w 2047 r. na poziomie ok. 37\%. W tym kontekście powstaje jednak pytanie, $\mathrm{w}$ jakim stopniu podnoszenie formalnej granicy wieku

${ }^{6} \mathrm{~W}$ przywoływanych badaniach współczynnik obciążenia demograficznego definiowany jest jako relacja liczby osób w wieku powyżej 65 lat do ogółu osób w wieku produkcyjnym (15-64 lat). Współczynnik obciążenia ekonomicznego to z kolei relacja ogółu osób niepracujących w wieku powyżej 65 lat do ogółu osób pracujących w wieku produkcyjnym (15-64 lat). 
emerytalnego wpływa na opóźnienie momentu opuszczania rynku pracy (efektywny wiek emerytalny), a tym samym na faktyczne wydłużenie okresu odprowadzania składek na ubezpieczenie emerytalne.

Wśród argumentów za podwyższeniem wieku emerytalnego w Polsce często wskazywany jest również pozytywny wpływ tego zabiegu na sytuację finansową Funduszu Ubezpieczeń Społecznych, który głównie ze względu na wypłatę świadczeń emerytalnych boryka się dziś z chronicznym deficytem pokrywanym z dotacji z budżetu państwa7 [Bobrowska 2013, s. 56; Klimkiewicz 2013, s. 48; Tkaczuk 2014, s. 202; Szczepański 2016, s. 744-745]. Należy jednak zauważyć, że takie twierdzenia są jedynie częściowo prawdziwe. Po pierwsze, w systemie opartym na formule zdefiniowanej składki sytuacja funduszu emerytalnego istotnie poprawia się $\mathrm{w}$ krótkim terminie, $\mathrm{tj}$. w okresie stopniowego podwyższania wieku emerytalnego, gdy liczba ubezpieczonych wzrasta, a liczba świadczeniobiorców maleje. W długim okresie pozytywny wpływ podwyższania wieku emerytalnego na sytuację finansową funduszu emerytalnego ogranicza się do zmniejszenia wysokości dopłat do emerytur minimalnych. Po drugie, wpływ podwyższenia wieku emerytalnego na pozostałe fundusze wyodrębnione w ramach FUS (rentowy, chorobowy oraz wypadkowy) nie jest jednoznaczny. Co prawda wydłużenie aktywności zawodowej spowoduje zwiększenie wartości składek przekazywanych do tych funduszy, nie jest jednak pewne, czy kwota ta zrekompensuje ich zwiększone wydatki (ze względu na stan zdrowia osoby starsze częściej korzystają ze świadczeń chorobowych i rentowych).

Większość ekonomistów utrzymuje, że podwyższenie wieku emerytalnego ma korzystny wpływ na sytuację makroekonomiczną kraju, w tym w szczególności na: poziom dochodów fiskalnych i skalę wydatków publicznych, rynek pracy oraz tempo wzrostu gospodarczego [Guzikowski 2012, s. 14-15]. Twierdzenia te, w swojej istocie słuszne, wymagają kilku komentarzy:

1) o ile wzrost dochodów fiskalnych wynikający z wydłużenia przeciętnej długości aktywności zawodowej jest oczywisty, to skala zmniejszenia wydatków publicznych jest już dyskusyjna (jak wspomniano, ograniczeniu kosztów wypłacanych emerytur towarzyszy konieczność finansowania innych świadczeń);

2) bezpośrednim skutkiem podwyższania wieku emerytalnego jest zwiększenie podaży pracy $\mathrm{w}$ gospodarce ${ }^{8}$. Niekiedy rodzi to obawy związane ze zwiększeniem poziomu bezrobocia, szczególnie wśród osób młodych [Niewiadomska 2013, s. 107]. Należy jednak podkreślić, że twierdzenia takie opierają się na błędnym założeniu, jakoby praca osób młodych i starych była substytucyjna. Co więcej,

7 W 2015 r. było to ponad 42 mld zł [Ważniejsze informacje... 2016].

8 Według szacunków wydłużenie wieku emerytalnego w Polsce spowoduje do 2020 r. wzrost zasobu siły roboczej o ok. 340 tys. osób, a do 2040 r. o ok. 650 tys. osób [Guzikowski 2012, s. 14]. 
w dłuższej perspektywie wcześniejsza dezaktywizacja zawodowa powoduje podniesienie kosztów pracy (wzrost podatków na sfinansowanie emerytur), a tym samym zmniejszenie popytu na pracę, co z kolei paradoksalnie utrudnia znalezienie pracy osobom młodym. Inną kwestią jest problem aktywności zawodowej osób starszych. Zgodnie z danymi GUS [2016a] współczynnik aktywności zawodowej mężczyzn w wieku 50-59 lat wynosił 70,5\%, a w wieku 60-64 lat-45,17\%. Współczynniki aktywności zawodowej dla kobiet wynosiły odpowiednio 57,2\% i $18,2 \%$. Podwyższaniu wieku emerytalnego muszą więc towarzyszyć działania zmierzające do podniesienia tych wskaźników. W przeciwnym razie wyższy wiek emerytalny przełoży się jedynie na wzrost liczby osób bezrobotnych oraz pobierających świadczenia socjalne z innych tytułów;

3) wzrost gospodarczy (poziom PKB) zależy od trzech czynników: podaży pracy, oszczędności oraz postępu technologicznego. Zasadniczo ustalenia w zakresie wieku emerytalnego nie wpływają jedynie na ten ostatni. Głównym kanałem oddziaływania zmian w zakresie wieku emerytalnego na PKB jest podaż pracy. Ogólnie zwiększenie zasobu siły roboczej korzystnie wpływa na tempo wzrostu gospodarczego. W kontekście podwyższania wieku emerytalnego pojawia się jednak pytanie o wydajność pracy osób starszych. Może się bowiem okazać, że po przekroczeniu pewnego wieku krańcowa wydajność pracy spada poniżej poziomu wynagrodzenia. Powoduje to, że jednostkowa produkcja jest niższa od poniesionych nakładów na stworzenie miejsca pracy, co w skali makro powoduje obniżenie PKB oraz generuje lukę inflacyjną [Domański 2012]. Poziom wieku emerytalnego może również w pewnym stopniu oddziaływać na oszczędności. W obliczu prognozowanych stóp zastąpienia wynikających z niskiego wieku emerytalnego można bowiem założyć, że ludzie zaczną oszczędzać dobrowolnie, co zwiększy kapitał w gospodarce, korzystnie oddziałując na tempo wzrostu PKB.

\section{Podsumowanie}

Spostrzeżenia poczynione w toku przeprowadzonych analiz pozwalają sformułować kilka istotnych wniosków. Po pierwsze, część z argumentów przytaczanych w dyskusji na temat minimalnego wieku emerytalnego nie znajduje uzasadnienia merytorycznego, wpływ innych jest z kolei dyskusyjny. Ponadto przytaczane argumenty mają różną moc, co powoduje, że różna powinna być też ich waga przy ustalaniu zasad kształtowania minimalnego wieku emerytalnego. Po drugie, przemiany społeczno-gospodarcze, a także kwestie finansowe związane z konstrukcją systemu emerytalnego powodują, że zrównywanie wieku emerytalnego kobiet i mężczyzn jest nie tylko konieczne z ekonomicznego punktu widzenia, ale również w pełni uzasadnione. Po trzecie, w systemie zdefinio- 
wanej składki wydłużenie aktywności zawodowej prowadzi do wzrostu wysokości świadczeń, co jest szczególnie istotne w obliczu prognozowanych niskich stóp zastąpienia. Po czwarte, podwyższanie wieku emerytalnego wpływa na podstawowe parametry makroekonomiczne, w tym na tempo wzrostu PKB oraz poziom bezrobocia. Przy czym o ile panuje zgoda, co do kierunku tego wpływu, to problemem wymagającym dalszych badań jest jego siła. Po piąte, czynniki o charakterze demograficznym przemawiają za podnoszeniem minimalnego wieku emerytalnego, ale mówiąc o starzejącym się społeczeństwie, należy mieć na uwadze, że proces ten nie wynika wyłącznie z wydłużania sią trwania życia jednostek. Po szóste, w związku z niskimi wskaźnikami aktywności zawodowej osób starszych podwyższanie wieku emerytalnego stanowi olbrzymie wyzwanie dla rynku pracy.

Biorąc pod uwagę przede wszystkim dwa ostatnie ze sformułowanych powyżej wniosków, trzeba więc wyraźnie podkreślić, że wszelkim zmianom w zakresie wysokości wieku emerytalnego muszą towarzyszyć reformy wspierające aktywność zawodową osób starszych, takie jak [Jurek 2011, s. 24; Guzikowski 2012, s. 18]: uelastycznienie momentu przechodzenia na emeryturę (możliwość łączenia pracy zawodowej i innych rodzajów aktywności, stopniowe opuszczanie rynku pracy dzięki elastycznym formom czasu pracy i zatrudnienia), stworzenie sieci instytucji oferujących opiekę nad osobami starszymi oraz dziećmi, a także wspieranie procesu kształcenia ustawicznego. Pożądanym kierunkiem zmian wydaje się również stymulowanie rozwoju dodatkowego (tj. dobrowolnego) systemu zabezpieczenia emerytalnego, który może stanowić skuteczną ochronę przed ryzykiem starości, w pewnej mierze niezależne od oficjalnego wieku emerytalnego [Szczepański 2016, s. 750; Jedynak 2016]. Bez równoczesnego podejmowania tego typu działań podwyższanie wieku emerytalnego nieuchronnie skutkuje pojawieniem się negatywnych konsekwencji zarówno dla społeczeństwa, jak i dla gospodarki.

Podsumowując rozważania, należy stwierdzić, że podwyższenie wieku emerytalnego w Polsce w 2012 r. co do zasady było słuszne. Arbitralne, oderwane od polityki społecznej i nastawione na realizację wyłącznie doraźnych celów wprowadzenie tych zmian stanowiło jednak poważny błąd rządzących. $\mathrm{Z}$ podobnych powodów, do których dodać trzeba omówione w artykule czynniki demograficzne i ekonomiczne, jeszcze większym błędem może się okazać planowane ponowne obniżenie wieku emerytalnego. Wynika z tego, że obecna dyskusja dotycząca długości aktywności zawodowej powinna koncentrować się przede wszystkim na aktywizacji zawodowej osób starszych oraz uelastycznianiu wieku przechodzenia na emeryturę. 


\section{Literatura}

Barr N., Diamond P. [2014], Reformy systemu emerytalnego, Krótki przewodnik, PTE, Warszawa.

Bednarczyk T.H. [2015], Wyzwania demograficzne dla systemów emerytalnych w Unii Europejskiej, ,Annales Universitatis Mariae Curie-Skłodowska”, Sectio H - Oeconomia, nr 49(2), https://doi.org/10.17951/h.2015.59.2.33.

Benio M. [2014], Podwyższanie wieku emerytalnego w Polsce przy użyciu instrumentów dobrego rzqdzenia, ,Zarządzanie Publiczne”, nr 1(27).

Bera A., Walczak D. [2012], Problematyka wieku emerytalnego w modernizacji polskiego systemu emerytalnego. Głos $w$ dyskusji, „Wiadomości Ubezpieczeniowe”, nr 1.

Bobrowska A. [2013], Emerytury a wynagrodzenia w Polsce - próba określenia sytuacji materialnej emerytów na tle pracujacych, „Konsumpcja i Rozwój”, nr 1.

Domański S.R. [2012], Wiek emerytalny, http://www.polishclub.org/2012/02/13/prof-dr-hab-s-ryszard-domanski-wiek-emerytalny/ (data dostępu: 29.09.2016).

European Commission [2015], The 2015 Ageing Report, „European Economy”, nr 3.

European Commission [2016], Mutual Information System on Social Protection, http:// www.missoc.org/ (data dostępu: 28.09.2016).

Eurostat [2016], Healthy Life Years Statistics, http://ec.europa.eu/eurostat/statistics-explained/index.php/Healthy_life_years_statistics (data dostępu: 28.09.2016).

Góra M. [2003], System emerytalny, PWE, Warszawa.

GUS [2016a], Aktywność ekonomiczna ludności Polski I kwartał 2016 roku, http://stat. gov.pl/obszary-tematyczne/rynek-pracy/pracujacy-bezrobotni-bierni-zawodowo-wg-bael/aktywnosc-ekonomiczna-ludnosci-polski-i-kwartal-2016-roku,4,20.html (data dostępu: 24.09.2016).

GUS [2016b], Stopa bezrobocia w latach 1990-2016, http://stat.gov.pl/obszary-tematyczne/rynek-pracy/bezrobocie-rejestrowane/ (data dostępu: 28.09.2016).

GUS [2016c], Trwanie życia, http://stat.gov.pl/obszary-tematyczne/ludnosc/trwanie-zycia/ (data dostępu: 28.09.2016).

Guzikowski M. [2012], Dlaczego musimy podwyższać ustawowy wiek emerytalny?, Analiza Forum Obywatelskiego Rozwoju, nr 06.

Jedynak T. [2016], Ryzyko starości a dodatkowy system emerytalny w Polsce, ,Zeszyty Naukowe Uniwersytetu Ekonomicznego w Krakowie", nr 8(956), https:/doi. org/10.15678/ZNUEK.2016.0956.0801.

Jończyk J. [2001], Prawo zabezpieczenia społecznego, Zakamycze, Kraków.

Jurek Ł. [2011], Rekonstrukcja wieku emerytalnego w dobie demograficznego starzenia. Porównanie alternatywnych modeli i rozwiqzań, „Polityka Społeczna”, nr specjalny: Problemy zabezpieczenia emerytalnego w Polsce i na świecie.

Klimkiewicz A. [2013], Zmiana granicy wieku emerytalnego jako element racjonalizacji wydatków emerytalnych, „Acta Universitatis Lodziensis”, Folia Oeconomica, nr 296.

Mind the Gap - Quantifying the Pension Savings Gap in Europe [2016], Aviva, http://www. aviva.com/media/thought-leadership/europe-pensions-gap/ (data dostępu: 20.09.2016).

Murkowski R. [2013], Wiek emerytalny w Polsce w kontekście przemian struktury ludności według wieku [w:] Współczesne zabezpieczenie emerytalne. Wybrane aspekty ekonomiczne, finansowe i demograficzne, red. F. Chybalski, E. Marcinkiewicz, Wydawnictwo Politechniki Łódzkiej, Łódź.

Muszalski W. [2009], Przemiany wieku emerytalnego, „Polityka Społeczna”, nr 3. 
Niewiadomska A. [2013], Ekonomiczne przesłanki podnoszenia wieku emerytalnego w społeczeństwach europejskich, „Ekonomia”, nr 1(22).

OECD [2015], Pensions at a Glance 2015: OECD and G20 Indicators, Paris, http://dx.doi. org/10.1787/pension_glance-2015-en.

Piotrowski J. [1966], Zabezpieczenie społeczne. Problematyka i metody, Książka i Wiedza, Warszawa.

Rutecka J. [2015], Świadczenia emerytalne a zaspokojenie zmieniających się potrzeb w okresie dezaktywizacji zawodowej, „Praca i Zabezpieczenie Społeczne”, nr 8.

Staniec I., Depta A. [2013], Identyfikacja czynników ekonomicznospołecznych wpływajqcych na różnice $w$ oficjalnym $i$ efektywnym wieku emerytalnym $w$ wybranych krajach [w:] Współczesne zabezpieczenie emerytalne Wybrane aspekty ekonomiczne, finansowe i demograficzne, red. F. Chybalski, E. Marcinkiewicz, Wydawnictwo Politechniki Łódzkiej, Łódź.

Szczepańska M. [2011], Równość płci a zróżnicowany wiek emerytalny, „Studia BAS”, nr 2(26).

Szczepański M. [2016], Analiza i ocena proponowanych zmian ustawowego wieku emerytalnego w Polsce, „Finanse, Rynki Finansowe, Ubezpieczenia”, nr 1(79), https://doi. org/10.18276/frfu.2016.79-58.

Szubert W. [1987], Ubezpieczenie społeczne. Zarys systemu, PWN, Warszawa.

Szumlicz T. [2005], Ubezpieczenie społeczne. Teoria dla praktyki, Oficyna Wydawnicza Branta, Bydgoszcz-Warszawa.

Tkaczuk M. [2014], Podnoszenie wieku emerytalnego a problemy polskiej polityki społecznej, Studia Ekonomiczne, nr 179, Uniwersytet Ekonomiczny w Katowicach, Katowice.

Ustawa z dnia 11 maja 2012 r. o zmianie ustawy o emeryturach i rentach z Funduszu Ubezpieczeń Społecznych oraz niektórych innych ustaw, Dz.U. nr 107 poz. 637.

Ważniejsze informacje z zakresu ubezpieczeń społecznych 2015 r. [2016], ZUS, http:// www.zus.pl/files/Wa\%C5\%BCniejsze\%20informacje\%20z\%20zakresu\%20ubezpiecze\%C5\%84\%20spo\%C5\%82ecznych\%202015\%20r.pdf (data dostępu: 29.09.2016).

Wyrok Trybunału Konstytucyjnego z dnia 15 lipca 2010 r., sygn. akt K 63/07 (OTK-A ZU nr 6 poz. 60)

Zieleniecki M. [2015], Kilka refleksji na temat podwyższenia wieku emerytalnego w Polsce (na marginesie wyroku Trybunału Konstytucyjnego w sprawie K 43/120), „Gdańskie Studia Prawnicze", nr 32.

\section{The Rationale for Determining the Level of the Minimum Retirement Age} (Abstract)

The study examines the principles of determining the minimum retirement age as one of the primary parameters of retirement systems. The main purpose of the article is to contribute the following to the ongoing debate on the official retirement age: methodical considerations, historical perspective and critical analysis of arguments which are put forward within the context of rising and equalising retirement age for women and men. Based on a review of the literature, epistemological considerations and also drawing on the latest empirical data, the role of the retirement age in modern old-age security systems was analysed. The arguments formulated for raising and equalising the retirement 
age for men and women are also discussed. The thesis proper of the paper is that the current socio-economic changes prompt the need to modify the previous approach to the age at which individuals end their professional activity. The analysis presented in the paper justifies this contention. However, the changes to the previous approach cannot be arbitrary, isolated from complex social policy or realise only short-term political goals.

Keywords: retirement age, retirement, pension system, equalising retirement age, raising retirement age. 